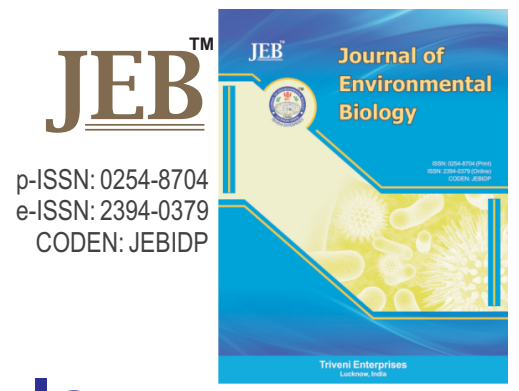

\title{
Salinity and drought stress on barley and wheat cultivars planted in Turkey
}

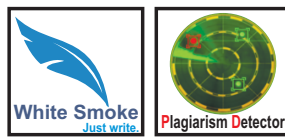

Authors Info

E. Yörük*, E.N. Keleş, Ö. Sefer and M. Eraslan

Department of Molecular Biology and Genetics, Faculty of Arts and Sciences, Istanbul Yeni Yuzyil University, Zeytinburnu, Istanbul, 34010, Turkey

*Corresponding Author Email : emre.yoruk@yeniyuzyil.edu.tr

Key words

Drought

Salinity

Stress

Water loss rate

Wheat cultivar

Publication Info Paper received : 21.07.2017 Revised received : 06.12 .2017 Re-revised received : 07.02 .2018 Accepted : 12.02 .2018

\begin{abstract}
Aim: The study was conducted to investigate the salinity and drought susceptibilities of barley and wheat varieties cultivated in Turkey by phenotypic assays and to evaluate the association of WRKY19 and WRKY52 transcription factors with salinity and drought stresses by gene expression assays.
\end{abstract}

Methodology: Salinity tests of treatment different concentration of $(0,0.5,1$ and $2 \%) \mathrm{NaCl}$ were managed with 13 barley and 22 wheat varieties germinated for 10 days. According to findings obtained from phenotypic investigations, two relative tolerant and two sensitive cultivars were selected and used in gene expression analysis. Transcript abundance for drought stress and relative fold changes for salinity stress were analyzed via expression assays of WRKY19 and WRKY52 genes.

Results: The minimum and maximum germination scores were changed between $0.090 \pm 0.090$ $3.818 \pm 0.400$ (barley) and $0.454 \pm 0.312-3.0913 \pm 0.594$ (wheat), while water loss rate (WLR) values ranged from $0.009 \pm 0.0091-0.2 \pm 0.0011$ (barley) and $0.01 \pm 0.0005-0.3 \pm 0.1195$ (wheat). In drought stress assessments, WRKY19 and WRKY52 transcripts abundances were relatively higher in relatively resistance cultivars in comparison to sensitive genotypes. Similarly, fold changes in gene expression were higher in resistant cultivars up to +26 changes.

Interpretation: Drought and salinity stress factor analysis showed that there was no homogenous abiotic stress response profile for barley and wheat varieties in Turkey. According to gene expression analysis, WRKY19 and WRK52 genes could stimulate the drought and salinity responses. This study is important in terms of analyzing the cereal varieties planted in Turkey, and providing an association between WRKY genes and abiotic stress.

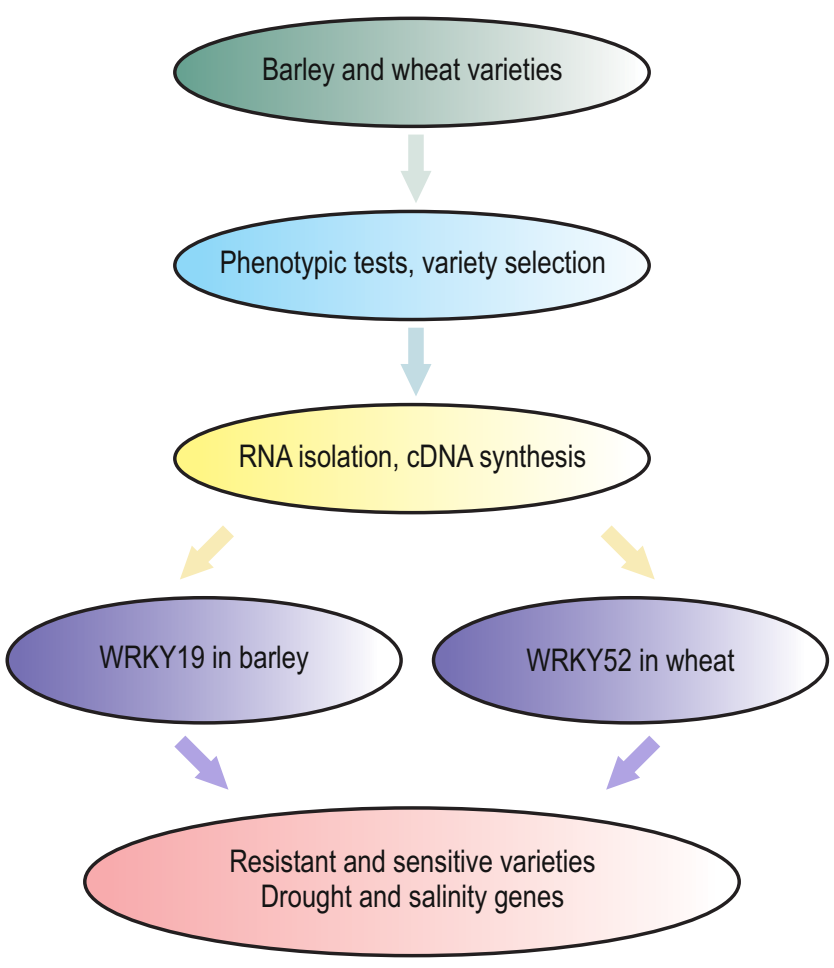




\section{Introduction}

Cereals have great importance in biotechnology, medicine, industry and providing the food sources. The plantation of cereals takes an important place in the economy of many developed and developing countries. According to food and agriculture organization (FAO) statistics, in Turkey the production of barley and wheat was 6 million and 19 million tons in the year 2014. Total yield production worldwide was 144 million and 729 million tons for wheat and barley. The total cereal production quantities in Turkey and worldwide were 32 million and 2 billion tons, respectively. These data reveal that conservation, sustainability and improvement in wheat and barley resources are essential and crucial for the continuity development of economic growth.

Barley and wheat are genetically closely related plant species of same taxonomic tribe, Triticale (Pourkheirandish and Komatsuda, 2007). Both crops have originated from primary agricultural places located in Fertile Crescent, including some parts of Turkey (Harlan and Zohary, 1966). Up to $95 \%$ of the genome nucleotide sequence for barley and wheat have been released in the databases, and currently barley has diploid $(2 n=14)$ genome of $5.1 \mathrm{~Gb}$. The annual species, accepted as model species, is self-pollinating with short life cycle and adaptable successfully to plant tissue cultures. Wheat has hexaploid genome $(6 n=52)$ of $17 \mathrm{~Gb}$. The species has great economic importance worldwide and has been adapted into many biotechnological processes (Forster et al., 2000; Brenchley et al. 2012; Mayer et al., 2012).

Barley and wheat are exposed to biotic and abiotic stress factors such as nematodes, fungi, drought and salinity. The drought and salt stress are major and the most common abiotic stress factors for these two economically important cereals worldwide and unfortunately increased population and pollution, low land area for agriculture, global warming have enhanced the drought and salinity stress, thereby decreasing the efficiency and quality of agriculture (Hu and Schmidhalter, 2005; Athar and Ashraf, 2009; Badridze et al., 2009; Yadav et al., 2011). However, plants have several kinds of mechanisms in order to develop resistance against stress factors. Tolerance response are mainly managed by several important genes, gene families or metabolites including, transcription factors (such as DREB and WRKY), microRNAs, hormones, co-factors and ions (Aktaş and Güven, 2005; Budak et al., 2015).

WRKY transcription factors belong to gene families which have the potential in playing a role in activating the signaling pathways and defense systems. This gene family is characterized with 60 amino acids of conserved regions including "WRKY" amino acids at least one time. The transcription factor has zinc finger motif DNA binding site and up to a hundred WRKY genes have been characterized only for wheat and barley on databases (Rushton et al., 1996; Eulgem et al., 2000; Fowler and
Thomashow, 2002; Singh et al., 2002; Seki et al., 2002). However, the limited data of precise association and annotation of WRKY transcription factors with abiotic and or biotic stress factor type are present. WRKY1, WRKY2, WRKY3, WRKY45 and WRKY38 are just some of these transcription factor which have been associated with in particular biotic stress factors in some important crops including Petroselinum crispum, Oryza sativa and Arabidopsis thaliana (Rushton et al., 1996; Marè et al., 2004; Rushton et al., 2010). The restricted number of annotated nucleotide sequence data about the WRKY genes with specific characteristics on databases including National Center for Biotechnology Informaton (NCBI) and European Molecular Biology Laboratory (EMBL) limits the further plant biotechnological investigations. Similarly, there is no precise synteny knowledge of WRKY genes for different plant species. Thus, genes possessing the WRKY domain should be cloned and annotated for each plant species separately. To the best our knowledge, wheat and barley cultivars used in this study have not been investigated in terms of their salinity and drought stress responses, and also WRKY19 and WRKY52 genes have not been associated with drought and salinity stress for wheat and barley previously. In view of the above, the present study aimed to determine the drought and salinity stress responses of wheat and barley cultivars planted in Turkey, and to reveal the potential association of WRKY19 and WRKY52 genes with drought and salt stress factors.

\section{Materials and Methods}

Plant materials : The seeds of barley and wheat varieties were procured from Istanbul Yeni Yuzyil University cultivar collection were used in this study. In total, 13 barley and 22 wheat varieties were used for phenotypic tests. Two varieties of relatively resistant and sensitive varieties were selected and used for QRTPCR analysis.

Salinity and water loss rate treatments : In total, 13 barley and 22 wheat varieties were used for salinity and potential drought resistant capacity investigations at early seedling stages. Four different sodium chloride concentrations were prepared in water, viz, 0 (as a control set), $0.25,0.5,1.0$ and $2.0 \%$ were used. Seven seeds per treatment of each cultivar, with at least three times, were germinated on filter paper in plastic boxes at $22 \pm 2{ }^{\circ} \mathrm{C}$ and 1:1 light/dark photoperiod. Three milliliter distil water per $9 \mathrm{~cm}$ plastic boxes were used for germination assays. Germination scores associated with no-salt, and salinity level in each variety were measured after 10 days, as described by Mano et al. (1996) with the scale including values from "0" to "9". Germination scores for each experiment set were calculated. Two varieties with relatively resistant and sensitive characteristics were selected for further analysis.

In addition to salinity assays, water loss rate (WLR) assays were used to obtain the knowledge of potential drought 
resistance of barley and wheat varieties. The procedure developed by Clarke and McCaig (1982) was followed. Seedlings were grown on moist filter paper in Petridishes at room temperature for 10 days. The expanded first green leaves were cut and fresh weight $\left(F_{w}\right)$ was recorded. The leaves were left on filter paper for $24 \mathrm{hrs}$ and then the moderately dried leaf weight $\left(W_{24}\right)$ was calculated. After that step, leaves were left at $80^{\circ} \mathrm{C}$ for $24 \mathrm{hrs}$ and dry weight $\left(D_{w}\right)$ was recorded. WLR was determined according to the formula given below:

$$
\text { WLR }\left[\mathrm{g} \mathrm{h}^{-1} \mathrm{~g}^{-1} D_{w}\right]=\left[F_{W}-W_{24}\right] /\left[D_{W} \times 24\right]
$$

Total RNA extraction and cDNA synthesis : Total RNA molecules of relatively resistant varieties and relatively sensitive barley and wheat varieties (Table 1) were isolated using TriReagent (Gene All, South Korea). A 50 mg of fresh plant tissues were homogenized via liquid nitrogen using sterile mortar and pestle. The homogenization was completed using $0.5 \mathrm{ml}$ TriReagent and then the manufacturer's recommendations were followed. The total RNAs extracted were analyzed via $0.8 \%$ agarose gel electrophoresis under UV light. The quantity of total RNAs were obtained using spectrophotometer (Thermo, U.S.A.). Total RNA molecules were immediately used in cDNA conversion. cDNAs were obtained with one-step kit (Takara, Japan) and then used in the qRT-PCR assays. cDNA synthesis was performed using $2 \mu \mathrm{g}$ RNA as the starting amount for all samples. CDNA synthesis was carried out in a volume of $10 \mu \mathrm{l}$, including $2 \mu \mathrm{g}$ RNA, $2.5 \mu \mathrm{M}$ Oligo dT Primer, $2.5 \mu \mathrm{M}$ Random hexamer primers, 1X PrimeScript Buffer, $10 \cup$ PrimeScript RTase enzyme and RNase free water. cDNAs, which were $1 / 4$ dilutes, were used in qRT-PCR assays.

qRT-PCR assays : In qRT-PCR assays, WRKY19 gene and WRKY52 genes were used as target gene for barley and wheat, respectively. Since the complete CDS of these genes are not present on NCBI for both plant species, only one target gene was used in qRT-PCR assays for each plant species. The target gene expression was normalized according to a-actin (KC775780.1, AY145451.1) expression. Wrky52-F (5' -ACGGCAAGAAGATGG TCAAG-3')/Wrky52-R(5' -TCGTAGGTGGTGATGACGAA-3'), Wrky19-F (5' -TCAACACCACTGCAAAGAGC-3')/Wrky19-R (5'AGAAGGCGAGATCGTTCAGA-3') and actin-F (5'GGCACACTGGTGTCATGGT-3')/actin-R (5'-GCGCCTCATCAC CAACATA-3') primer molecules were designed using "Primer 3" software. Absolute quantification and relative quantification strategies were used for WLR and salinity assays, respectively. Light Cycler 480 II (Roche, Swiss) system was used in Sybr Green I (Takara, Japan) fluorescent dye accompanied assays. qRT-PCR assays were done in a reaction volume of $12 \mu \mathrm{l}$ containing 1X Sybr Green I mix, 2 pmol each primer and amount of cDNA corresponding to $2 \mu \mathrm{g}$ RNA. Cycling conditions were at $95^{\circ} \mathrm{C}$ for $2 \mathrm{~min}$, followed by 45 cycles of $95^{\circ} \mathrm{C}$ for $10 \mathrm{sec}, 57^{\circ} \mathrm{C}$ for $15 \mathrm{sec}, 72^{\circ} \mathrm{C}$ for $20 \mathrm{sec}$ and cooling step at $40^{\circ} \mathrm{C}$ for $30 \mathrm{sec}$. Melting curve analysis and standard series consisting of 5 logarithmic phases were also used. Gene expression profiles were obtained according to $2^{-\triangle \Delta C T}$ normalization values (Livak and Schmittgen, 2001) or mRNA transcript abundance based absolute quantification assays. The experiments were replicated three times.

Statistical analysis : The statistical data obtained from phenotypic tests and qRT-PCR assays were analyzed by GraphPad Prism 5.0 (Dr. Harvey Motulsky, U.S.A.) software using one-way analysis of variance (ANOVA). Significance of differences was calculated by Tukey's post-hoc test with $0.05 \mathrm{Cl}$ level. Mean and standard deviation values were obtained using column statistics.

\section{Results and Discussion}

In the present study, in total 35 barley and wheat germplasms were subjected to salinity and potential drought stress tolerance capacity determination analysis. In salinity assays, each variety showed no germination at $2 \% \mathrm{NaCl}$ concentration. Experiments set with increased $\mathrm{NaCl}$ concentrations led to decreased germination scores in both barley and wheat varieties (Fig. 1). The decrease was significantly important $(p<0.05)$. While germination scores were between 8.636 and 2.727 in control treatment, minimum and maximum germination scores range of 5.909 and $1.818,5,00$ and $1.273,4.091$ and 0.818 and 3.0913 and 0.454 were detected for $0.25,0.5,0.75$ and $1.0 \mathrm{NaCl}$ treatment (Fig. 1), respectively. According to cumulative germination scores, relatively resistant and tolerant varieties were determined (Table 1) and then they were used in qRT-PCR assays. Significantly decreased growth capacity due to $\mathrm{NaCl}$ treatment in wheat and barley varieties was an expected result since $\mathrm{NaCl}$ causes salinity stress. Similar results were also reported for plants species such as rice and sorghum (Bagdi and Shaw, 2013; Almodares et al., 2014; Bagdi et al., 2015). However, the germination scores obtained from salinity assays showed that there was no homogenous profile for salinity response capacity among varieties planted in Turkey. Up to 6.8 fold resistance level were detected between varieties $H$. vulgare $L$ cv. Oliver and $H$. vulgare L cv. Karatay; 42.4 folds changes were detected between $T$. aestivum $L$ cv. Glosa and T. aestivum $L \mathrm{cv}$. Bezozya, confirming that varieties planted in Turkey could be used in comprehensive and detailed genotype and ecotype comparison analysis against some important genotypes such as H. vulgare L. Cv. Tokak 157/37 (which was already used in this study), H. vulgare L. cv. Golden Promise, T. aestivum L. Cv. Sumai-3 etc.

In potential drought stress tolerance assays, WLR values were recorded from each variety. The mean WLR values for barley varieties ranged from $0.0091(H$. vulgare $L \mathrm{cv}$. Oliver) to $0.22[H$. vulgare L cv. Marmara-86 (2b) (Table 2). The minimum and maximum mean WLR values in wheat varieties were 0.0186 (T. aestivum L cv. Antille) and 0.3045 (T. aestivum L cv. Mv. Suba 

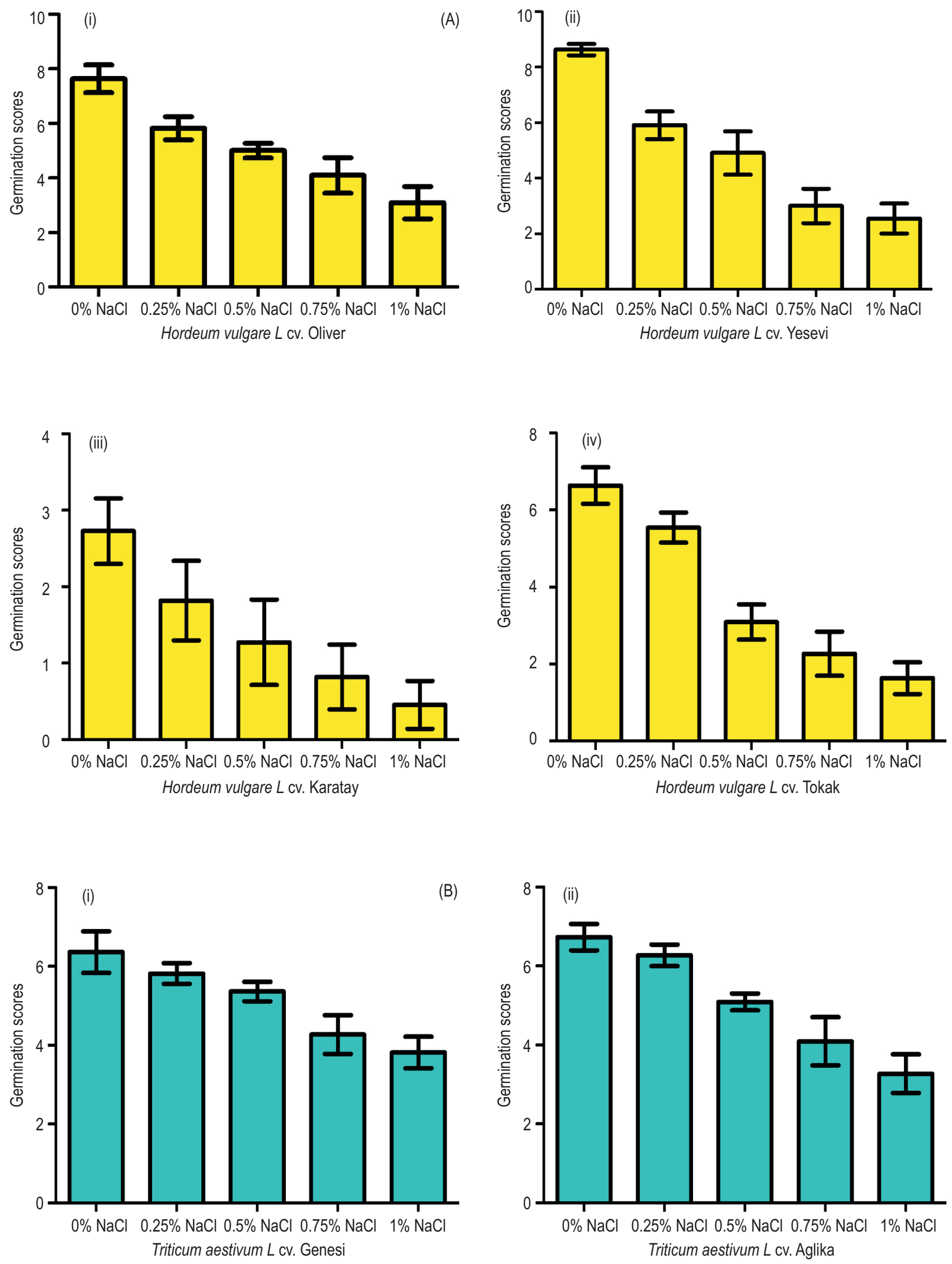

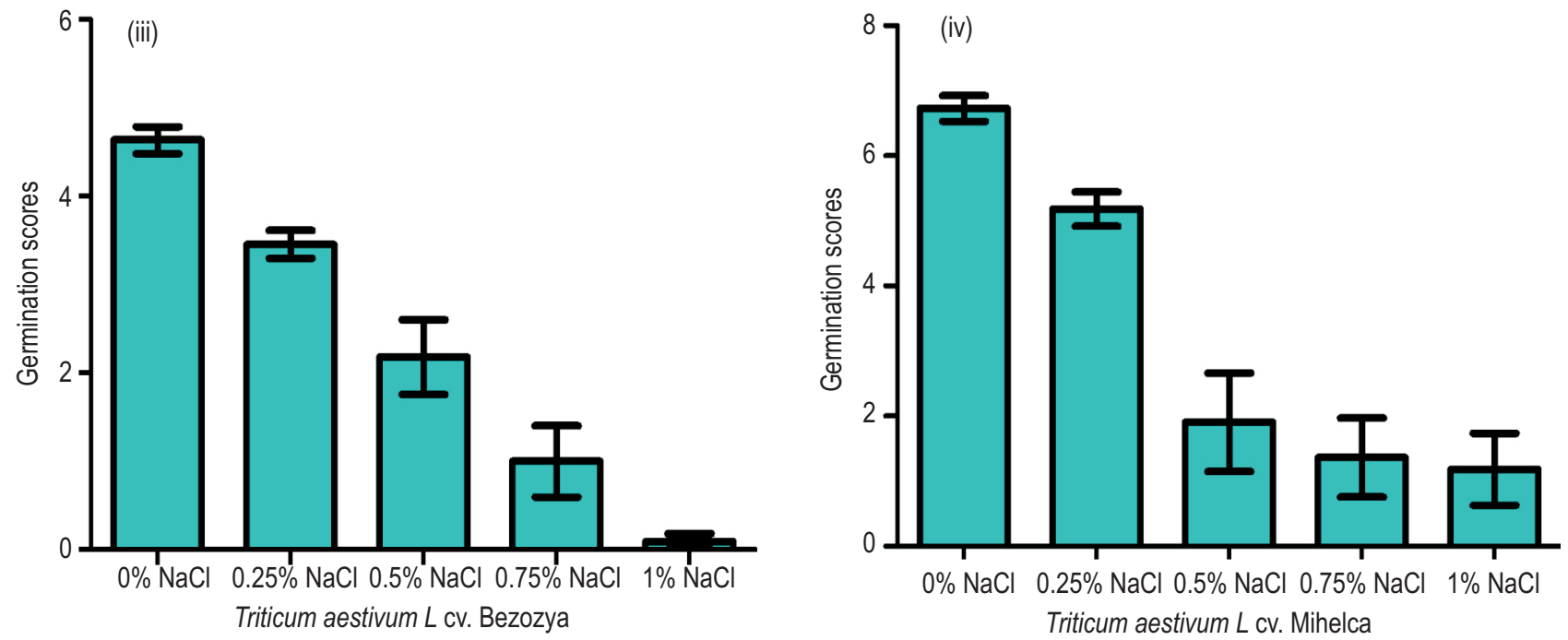

Fig. 1 : Resistant and sensitive barley ( $\mathrm{A}$ i-iv) and wheat ( $\mathrm{B}$ i-iv) varieties determined by germination scores related to salt stressassays. Graphic shows the association of increased $\mathrm{NaCl}$ concetnrations and decreased germination scores for barley and wheat varieties.
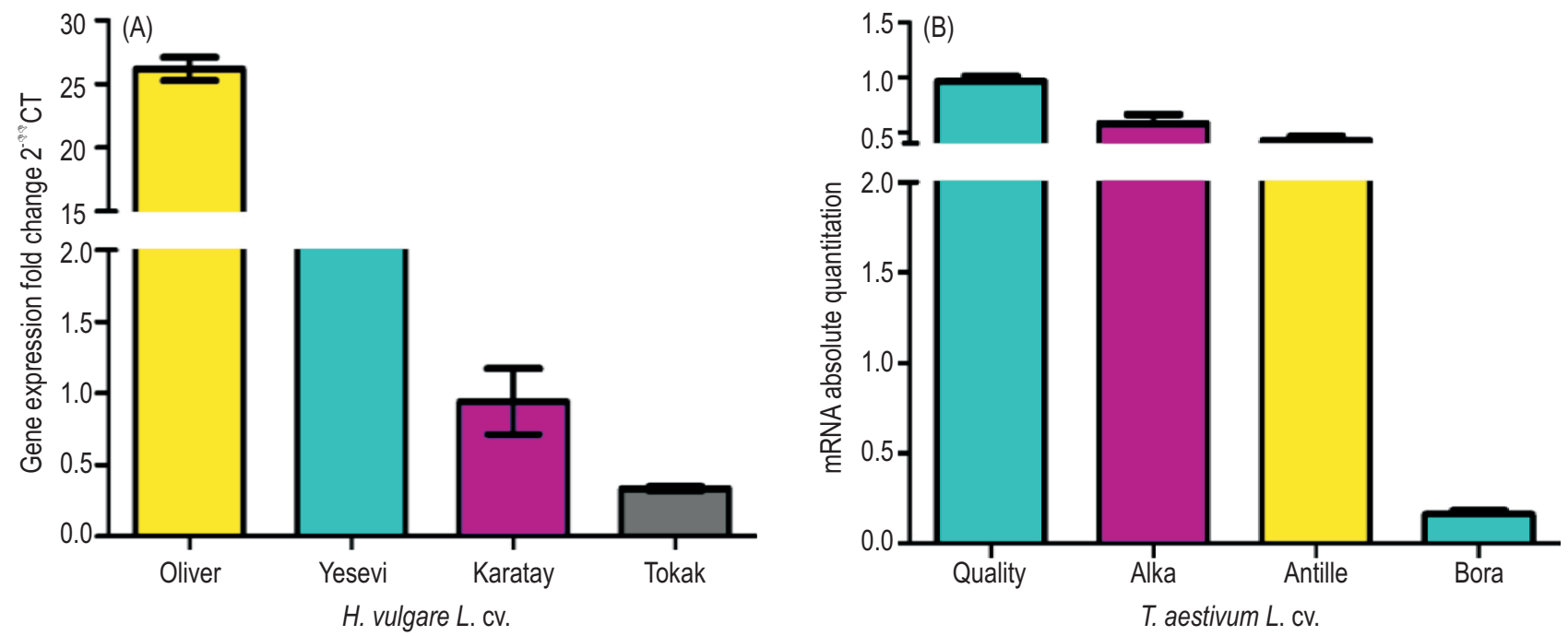

Fig. 2 : Fold changes in WRKY19 expression (A) and mRNA transcript abundance based absolutequantitation of WRKY52 (B)in relatively resistant and sensitive barley and wheat genotypes. The graphic illustrates the changes in gene expression related to drought and salinity stres response potentials of varieties.

prebasic), respectively. In comparision to studies including WLR assays of wheat and barley genotypes (Suprunova et al., 2004; Gürel et al., 2016), WLR values varied resulting in the presence of both relatively resistant and sensitive varieties for plant materials used in this study. The results showed that potential drought resistant barley varieties $H$. vulgare L. cv. Marmara $2 b$ and $2 k$, which were planted in Marmara and Southeastern area of Turkey, could be used in more agro-ecological regions. In fact, the seeds of these two resistant varieties could be planted in Thrace and Central Anatolia regions, where relatively drought sensitive barley varieties $H$. vulgare L. cv. Tokak, Yesevi and Oliver have already been planted. Similarly, relatively drought resistant $T$. aestivum $\mathrm{L}$. cv. Alka and Quality varieties could be also planted in the Marmara region and Eastern Thrace, where relatively sensitive varieties were planted.

In gene expression analysis, firstly four barley and wheat varieties were selected according to their WLR and germination scores of salinity analysis. In high quality (A260/280= 1.9-2.0) and quantity $\left(1-2.5 \mu \mathrm{g} \mathrm{l}^{-1}\right)$, total RNAs were extracted from fresh tissues of control and experiment sets. cDNAs were immediately converted from $2 \mu \mathrm{g}$ total RNA molecules. a-actin gene was used 
Table 1 : Relatively resistant and sensitive barley and wheat varieties selected for both salinity and also drought stresses according to the results obtained from physiological tests

\begin{tabular}{lllll}
\hline Genotype & \multicolumn{4}{c}{ Abiotic strees type and plant species } \\
\cline { 2 - 5 } & Salinity/Barley & Salinity/Wheat & Drought/Barley & Drought/Wheat \\
\hline Resistant & H. vulgare L. cv. Oliver & T. aestivum L. cv. Genesi & H. vulgare L. cv. Marmara 86 2b & T. aestivum L. cv. Alka \\
& H. vulgare L. cv. Yesevi-93 & T. aestivum L. cv. Aglika & H. vulgare L. cv. Clarica & T. aestivum L. cv. Quality \\
Sensitive & H. vulgare L. cv. Karatay & T. aestivum L. cv. Bezozya & H. vulgare L. cv. Yesevi-93 & T. aestivum L. cv. Bora \\
& H. vulgare L. cv. Tokak157/37 & T. aestivum L. cv. Mihelca & H. vulgare L. cv. Tokak 157/37 & T. aestivum L. cv .Antille \\
\hline
\end{tabular}

Table 2: Water Loss Rate(WLR) values obtained from physiological tests of barley and wheatvarieties used in this study. The seedlings of 10 days were used for determining the potential drought stress responses of varieties

\begin{tabular}{|c|c|c|c|}
\hline Genotype & Mean WLR & Genotype & Mean WLR \\
\hline H. vulgare Lcv. Cervoise & 0.0119 & T. aestivum Lcv. Bezozya & 0.0330 \\
\hline H. vulgare L cv. Clarica & 0.0809 & T. aestivum L cv. Bona dea & 0.0190 \\
\hline H. vulgare L cv. Escadre & 0.0385 & T. aestivum Lcv. Bora & 0.0290 \\
\hline H. vulgare L cv. Gazda & 0.0447 & T. aestivum L cv. Canik & 0.1671 \\
\hline H. vulgare Lcv. Karatay & 0.0682 & T. aestivum Lcv. Ceyhan 99 & 0.0217 \\
\hline H. vulgare L cv. Larende & 0.0686 & T. aestivum L cv. Dropia & 0.0513 \\
\hline H. vulgare Lcv. Lord & 0.0449 & T. aestivum Lcv. Esperia & 0.0283 \\
\hline H. vulgare Lcv. Marmara-86 (2b) & 0.2293 & T. aestivum L cv. Flamura 85 & 0.0476 \\
\hline H. vulgare L cv. Marmara-86 (2k) & 0.0608 & T. aestivum Lcv. Forblanc & 0.0233 \\
\hline H. vulgare L cv. Oliver & 0.0091 & T. aestivum Lcv. Genesi & 0.0341 \\
\hline H. vulgare Lcv. Premium & 0.0111 & T. aestivum Lcv. Glosa & 0.0617 \\
\hline H. vulgare L cv. Tokak 157/37 & 0.0203 & T. aestivum L cv. Iridium & 0.0205 \\
\hline H. vulgare Lcv. Yesevi-93 & 0.0118 & T. aestivum Lcv. Karakýlçýk & 0.0186 \\
\hline T. aestivum L cv. Adagio & 0.0777 & T. aestivum L cv. Mihelca & 0.0481 \\
\hline T. aestivum L cv. Adelaide & 0.0248 & T. aestivum L cv. Mv. Suba basic & 0.0381 \\
\hline T. aestivum L cv. Aglika & 0.0207 & T. aestivum L cv. Mv. Suba prebasic & 0.3045 \\
\hline T. aestivum Lcv.Alka & 0.2085 & T. aestivum L cv. Nomade & 0.1356 \\
\hline T. aestivum Lcv. Antille & 0.0186 & T. aestivum L cv. Qalitiy & 0.1913 \\
\hline
\end{tabular}

in normalization for both absolute quantification and relative quantification analysis. Mean E value was recorded as 1.975. The mean melting score for three genes was as 0.95 . The findings showed that qPCR analysis was performed accurately and efficiently. $\triangle C p$ values for treated and untreated sets of WRKY19/WRKY52 gene in barley/wheat were calculated as $4.921 / 6.2$ and 11.15/11.57, respectively. Fold changes in WRKY19 for barley varieties was ranged from $26.19(p<0.001)$ to 0.336 ( $p<0.001)$, whereas WRKY52 fold changes for wheat varieties were between $14.46(p<0.001)$ to $+0.206(p<0.001)$ (Fig. 2). It was observed, that these changes in gene expressions were found to be significantly different. In absolute quantification analysis for association with potential drought resistance investigations, normalization values for WRKY19 gene ranged from $0.01 \pm 0.001 \quad(p<0.001)$ to $0.55 \pm 0.03$ in barley varieties. Similarly,WRKY52 mRNA transcript abundance levels were between $0.016 \pm 0.002(p<0.001)$ to $0.96 \pm 0.049$ (Fig. 2). Both relative quantification and also absolute quantification analysis showed that there was a significant intra-variation among varieties of wheat and barley. These results mean that these selected varieties could be further used in agricultural and scientific investigations in terms of providing sensitive and resistant cultivars. Moreover, WRKY19 and WRKY52 could be effective and could play a key role in activating genes associated with drought and salinity stress responses in two economically important crops of wheat and barley. Similar results including alterations in gene expression via qRT-PCR strategy have also been obtained from some important plants such as rice and sugarcane (Bagdi et al., 2015; Jain et al., 2016). Since qRT-PCR strategy is fast, powerful and reliable tool for gene expression analysis, findings of this kind of studies could provide informative output for further studies associated with plant physiology and molecular plant sciences.

WRKY proteins could present resistance to abiotic and in particular biotic stress factors via their 3-D configuration based functions. WRKY1, WRKY2 and WRKY3 proteins have been associated with fight against phytopathogenic organisms in family umbelliferae. Additionally, over-expression of OsWRKY45 provided tolerance to pathogen related diseases, salinity and 
drought (Rushton et al., 2010). However, investigations of zinc finger motif including ABA dependent transcription family WRKYs has been found to be mainly associated with biotic stress tolerance, and majority of studies have been carried out on Oryza sativa, Arabidopsis thaliana and Nicotiana tabacum (Eulgem et al., 2000; Robatzek and Somssich, 2002; Rushton et al., 2010; Niu et al., 2012; Wang et al., 2015). The findings of this study is important in presenting for the first time the use of relatively high number of cereal varieties planted in different agro-ecological regions of Turkey, in order to investigate the drought and salinity resistance level. Also, WRKY19 and WRKY52 genes, in association with barley and wheat, could be used in further studies including epigenetics alterations, genetic modifications targeting drought and/or salinity resistant plant species or subspecies. The findings are important not only in presenting abiotic stress response variation of varieties used in agriculture in Turkey, but also life sciences investigations associated with modern genetics approaches.

\section{Acknowledgment}

This study was supported by Board Regents of Istanbul Yeni Yuzyil University. Dr. Emre Yörük is the main author of the article.

\section{References}

Aktaş, Y.L. and A. Güven: Bitki savunma sistemlerinde hormonal sinyal moleküler ve çapraz iletişimleri.J. Arts Sci., 3, 1-12 (2005).

Almodares, A., M.R. Hadi, B. Kholdebarin, B. Samedani and A Kharazian: The response of sweet sorghum cultivars to salt stress and accumulation of $\mathrm{Na}^{+}, \mathrm{Cl}^{-}$and $\mathrm{K}^{+}$ions in relation to salinity. J. Environ. Biol., 35, 733-739 (2014).

Athar, H.R. and M. Ashraf: Strategies for crop improvement against salinity and drought stress: An overview. TAVS, 44, 1-16 (2009).

Badridze, G., A. Weidner and F. Asch: Variation in salt tolerance within a Georgian wheat. Genet. Resour. Crop Evol., 56, 1125-1130 (2009).

Bagdi, D.L. and B.P. Shaw: Analysis of proline metabolic enzymes in Oryza sativa under $\mathrm{NaCl}$ stress. J. Environ. Biol., 34, 677-681 (2013).

Bagdi, D.L., B.P. Shaw, B.B. Sahu and G.K. Purohit: Real time PCR expression analysis of gene encoding p5cs enzyme and proline metabolism under $\mathrm{NaCl}$ salinity in rice. J. Environ. Biol., 36, 955961 (2015).

Brenchley, R., M. Spannagl, M. Pfeifer, G.L.A Barker, R. D'Amore, R. A.M. Allen, N. McKenzie, M. Kramer, A. Kerhornou, D. Bolser, S. Kay, D. Waite, M. Trick, I. Bancroft, Y. Gu, N. Huo, M. Luo, S. Sehgal, B. Gill, S. Kianian, O. Anderson, P. Kersey, J. Dvorak, W.R. McCombie, A. Hall, K.F.X Mayer, K.J Edwards, M.W Bevan and N. Hall: Analysis of the bread wheat genome using whole-genome shotgun sequencing. Nature, 491, 705-710 (2012).

Budak, H., B. Hussain, Z. Khan, N.Z Oztur and N. Ullah: From genetics to functional genomics: Improvement in drought signaling and tolerance in wheat. Front. Plant. Sci., 6,1012 (2015).

Clarke, J.M. and T.N. McCaig: Evaluation of techniques for drought resistance in wheat. Crop Sci., 22, 503-506 (1982).
Eulgem, T., P.J. Rushton, S. Robatzek and I.E. Somssich: The WRKY superfamily of plant transcription factors.Trends. Plant. Sci., $\mathbf{5}$, 199-206 (2000).

Forster, B.P., R.P. Ellis, W.T.B. Thomas, A.C. Newton, R. Tuberosa, D. This, R.A. El-Eneın, M. Bahri and M. Ben Salem: The development and application of molecular markers for abiotic stress tolerance in barley. J. Exp. Bot., 51, 19-27 (2000).

Fowler, S. and M.F. Thomashow: Arabidopsis transcriptome profiling indicates that multiple regulatory pathways are activated during cold acclimation in addition to the CBF cold response pathway. Plant Cell, 14,1675-90 (2002).

Gürel, F., N.Z Öztürk, E. Yörük, C. Uçarlı and N. Poyraz: Comparison of expression patterns of selected drought-responsive genes in barley (Hordeum vulgare L.) under shock-dehydration and slow drought treatments. Plant Growth Regul., 80, 183-193 (2016).

Harlan, J.R. and D. Zohary: Distribution of wild wheats and barley. Science, 153,1074-1080 (1966).

$\mathrm{Hu}, \mathrm{Y}$. and U. Schmidhalter: Drought and salinity: A comparison of their effects on mineral nutrition of plants. J. Plant Nutr. Soil Sci., 168, 541-549 (2005).

Jain, R., S.P. Singh, A. Singh, S. Singh, P. Tripathi, A. Chandra and S. Solomon: Study on physio-biochemical attributes and metallothionein gene expression affected by chromium (VI) in sugarcane (Saccharum spp. hybrid). J. Environ. Biol., 37, 375-382 (2016).

Livak, J.K. and T.D. Schmittgen: Analysis of relative gene expression data using real time quantitative PCR and the $2^{-\triangle A C T}$ method. Methods, 25, 402-408 (2001).

Mano, Y., H. Nakazumi and K. Takeda: Varietal variation in and effects of some major genes on salt tolerance at the germination stage in barley. Breed. Sci., 46, 227-233 (1996).

Marè, C., E. Mazzucotelli, C. Crosatti, E. Francia, A.M. Stanca and L. Cattivelli: HvWRKY38: A new transcription factor involed in coldand drought- response in barley. Plant Mol. Biol., 55, 309-416 (2004).

Mayer, K.F., R. Waugh, J.W. Brown, A. Schulman, P. Langridge, M. Platzer, G.B. Fincher, G.J. Muehlbauer, K. Sato, T.J. Close, R.P. Wise and N. Stein: A physical, genetic and functional sequence assembly of the barley genome. Nature, 491, 711-717 (2012).

Niu, C.F., W. Wei, Q.Y. Zhou, A.G Tian, Y.J. Hao, W.K. Zhang, B. Ma, Q. Lin, Z.B. Zhang, J.S. Zhang and S.Y. Chen: Wheat WRKY genes TaWRKY2 and TaWRKY19 regulate abiotic stress tolerance in transgenic Arabidopsis plants. Plant Cell Environ., 35, 1156-1170 (2012).

Pourkheirandish, M. and T. Komatsuda: The importance of barley genetics and domestication in a global perspective. Ann. Bot., 100, 999-1008 (2007).

Robatzek, S. and I.E. Somssich: Targets of AtWRKY6 regulation during plant senescence and pathogen defense. Genes Dev., 16, 11391149 (2002).

Rushton, P., J.T. Torres, M. Parniske P. Wernert, K. Hahlbrock and L.E. Somssich: Interaction of elicitor-induced DNA binding proteins with elicitor response elements in the promoters of parsley PR1genes. EMBO J., 15, 5690-5700 (1996).

Rushton, P.J., I.E. Somssich, P. Ringler and Q.J Shen: WRKY transcription factors. Trends. Plant Sci., 769,12 (2010).

Seki, M., M. Narusaka, J. Ishida, T. Nanjo, M. Fujita, Y. Oono, A. Kamiya, M. Nakajima, A Enju, T. Sakurai, M. Satou, K. Akiyama, T. Taji, K. Yamaguchi-Shinozaki, P. Carninci, J. Kawai, Y. Hayashizaki and K. 
Shinozaki: Monitoring the expression profiles of 7000 Arabidopsis genes under drought, cold and high-salinity stresses using a fulllength cDNA microarray. Plant J., 31, 279-92 (2002).

Singh, K.K., M.M. Das, A.K. Samanta, S.S. Kundu and S.D. Sharma: Evaluation of certain feed resources for carbohydrate and protein fractions and in situ digestion characteristics. Indian J. Anim. Sci., 72, 794-797 (2002)

Suprunova, T., T. Krugman, T. Fahıma, G. Chen, I. Shams, A. Korol and E. Nevo: Differential expression of dehydrin genes in wild barley,
Hordeum spontaneum, associated with resistance to water deficit. Plant Cell Environ., 27, 1297-1308 (2004).

Wang, X., J. Zeng, Y. Li, X. Rong, J. Sun, T. Sun, M. Li, L. Wang, Y. Feng, R. Chai, M. Chen, J. Chang, K. Li, G. Yang and G. He: Expression of TaWRKY44, a wheat WRKY gene, in transgenic tobacco confers multiple abiotic stress tolerances. Front. Plant. Sci., 6, 615(2015).

Yadav, S., M. Irfan, A. Ahmad and S. Hayat: Causes of salinity and plant manifestations to salt stress: A review. J. Environ. Biol., 32, 667$685(2011)$. 